\title{
Tectonics analysis on Amazon using GPR data
}

Gomes, G.Z.'; Silva, C.L. ${ }^{1}$; Martins, S.S. ${ }^{1,2}$; Morales, N. ${ }^{3}$

${ }^{1}$ Universidade Federal Rural do Rio de Janeiro; ${ }^{2}$ INCT da Criosfera/CNPq; ${ }^{3} \mathrm{DPM} / \mathrm{UNESP}$ (Rio Claro)

Copyright 2018, SBGf - Sociedade Brasileira de Geofísica

Este texto foi preparado para a apresentação no VIII Simpósio Brasileiro de Geofísica, Salinópolis, 18 a 20 de setembro de 2018. Seu conteúdo foi revisado pelo Comitê Técnico do VIII SimBGf, mas não necessariamente representa a opinião da SBGf ou de seus associados. É proibida a reprodução total ou parcial deste material para propósitos comerciais sem prévia autorização da SBGf.

\begin{abstract}
For an analysis of the region of Manaus (AM), they were of great importance the collection and analysis of GPR data. GPR, has become increasingly popular in the acquisition of geophysical data because it is a device that presents greater ease in its operation. But although it does not require a deep understanding of physical concepts, it is of great importance for the operator to know the fundamental concepts of the method and also understand about data collection and processing. The processing of the data collected by GPR consisted in the treatment and filtering of images applying filters and gains, thus facilitating their identification and interpretation. This processing allowed the visualization of supposed faults in places that have a high factor of weathering and of difficult surface observation.
\end{abstract}

\section{Introduction}

Studies on tectonics in the Paleozoic basin of Amazonas have shown a large number of structures (faults and fractures) that cut off the Cretaceous sequence and even the pedogenetic (lateritic) horizon in the tectonic context of Cenozoic deformations (Silva 2005; Silva et al. 2007; Val et al. 2014). The mapping of these structures has been carried out mainly in urban areas or road crossings, considering the intrinsic characteristics of the region, such as dense vegetation cover, difficult access and thick alteration layer. The exposure of subsurface particles or horizons that have been displaced by lamps have been exposed from the artificial exposure. This fact has made geological-structural mapping difficult. In this sense, the use of geophysical tools, such as GPR (Ground Penetrating Radar), allows to advance in the characterization of these subsurface structures. The use of GPR in Amazonia is not new and the first research carried out by Sauck et al. (1992) have already demonstrated satisfactory results but used only as a way of calibrating the equipment without in-depth structural analysis. In this context, the main objective of this study is to investigate the Cenozoic tectonics of the Manaus region by applying the survey in the Rio Negro Fault Zone (Silva 2005) in two locations, in the urban area of the city, where the structural data were obtained in a systematic way. In order to advance in this geological-structural characterization, the profiles surveyed (in 2003) were carried out at the base of the cuts that present important structural features, mainly involving weathered layers.

The GPR data used for structural characterization of the region allowed the recognition of sites more affected by the deformation and the layout of the structures and their types in depth of the order of up to 12 meters.

\section{Regional Geology}

The study area (Figure 1), located in the geological context of the Paleozoic Basin of Amazonas, basically involves sandy and clayey layers of the Alter do Chão Formation (Cretaceous/ Paleogenous), very weathered. The basal level, occurring near in the river is formed by sandstone and / or reddish silt under a very altered reddish layer. Above this package, with thickness of the order of a few meters, occurs the whitish level formed by kaolinized clayey and sandy intercalation. The soil horizon developed above corresponds to the sequence of the mottled level, superimposed by the yellowish clayey horizon, with lateritic concrete surface (10 to $30 \mathrm{~cm}$ thick), sometimes thin (pisolithic) and, at the top, the clay layer compact and slightly thick organic soil.

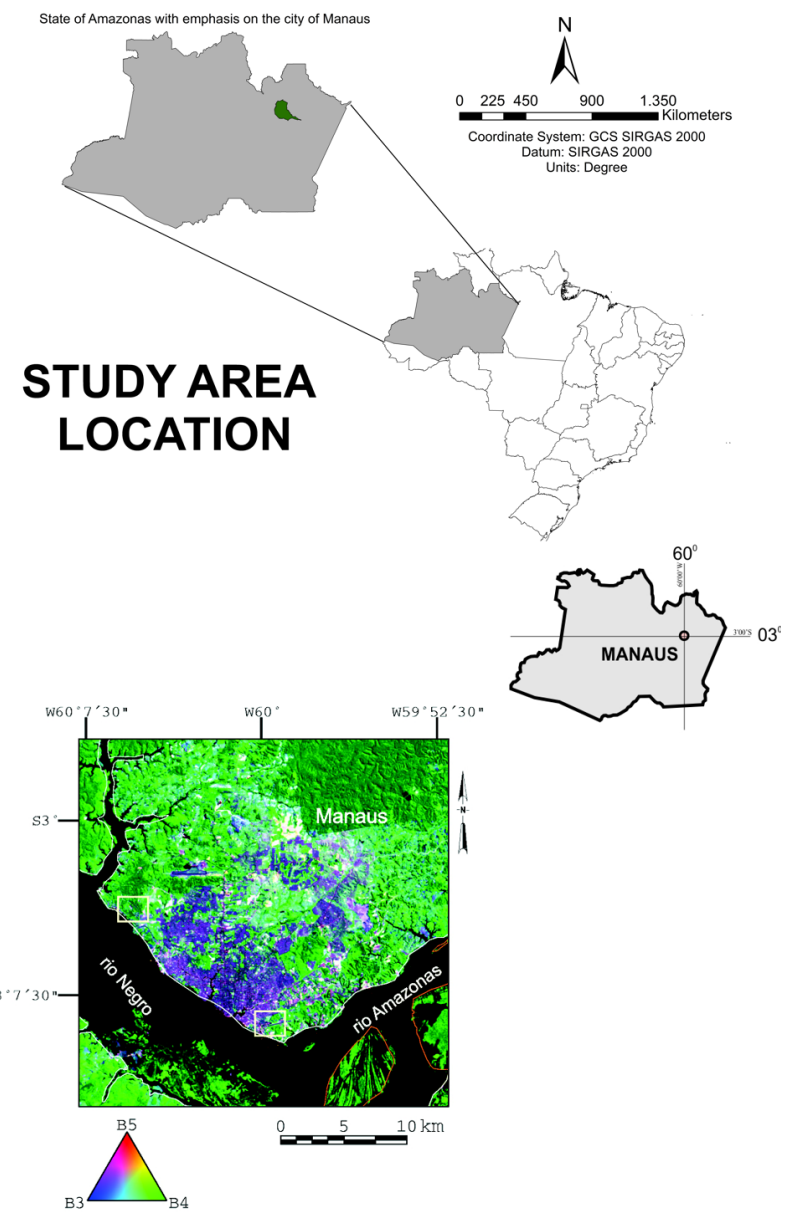

Figure 1 - Study area. The northwest area represents the Turismo avenue and the southest part represents the Rio Negro margins. 
The tectonic context in this region, based on Silva (2005), Silva et al. (2007) and Val et al. (2013, 2014) shows the existence of faults that cut through this sequence and control the relief and drainage of the region. According to Silva (2005), in the region of Manaus, the Rio Negro Fault Zone is a structure with direction N30W, which develops faults with dips both to the southwest and northeast and that controls the orientation of this river for almost $120 \mathrm{~km}$ to the region of the river Ariaú, west of the said city (Silva et al., 2007). The exposure of faults and fractures of this tectonic deformation is remarkable in road cutting and roads in the urban area of this city.

\section{Field Work and Processing}

In this study two types of GPR were used for the acquisition of data. The first one was an $80 \mathrm{MHz}$ MLF GSSI GPR, unshielded, composed by two antennas (transmitter and receiver), $80 \mathrm{MHz}$ frequency, $12 \mathrm{~ns}$ of pulse length with a data acquisition computer connected by cables. The second one was a SUBECHO 70 type, with $70 \mathrm{MHz}$ frequency, shielded, with only one antenna (transmitter and receiver). In both cases, the survey performed preferably followed the Step Mode, where about $90 \mathrm{~km}$ of GPR data were obtained along the highways of the region. For detailed, step-by-step walking was carried out in two areas: one located to the north and the other to the south, of that city, both located near the Rio Negro. For the first equipment was necessary a wooden car adapted with support wheels and an odometer in the back. In the front, next to the main vehicle, was placed the transmitter antenna with the receiver antenna in the other part.

The data processing was done in Reflex software, with the purpose of filtering and improving the visualization of the lines, thus allowing the recognition of geological features such as possible faults. The following filters and gains were selected as the processing flow: Subtracting mean (Dewow), AGC Gain, static correction, bandpass frequency, and a manual gain in time. The subtracting mean (Dewow) is a high-pass filter; the AGC gain, which acts on each trace independently, creates equally distributed amplitudes on the time-axis within a predefined window, this gain is used to highlight the low amplitude bands over the high amplitude bands; the bandpass frequency was used to eliminate low and high noise frequency and finally was applied a manual gain to improve quality of the deepest reflectors.

\section{Results}

The GPR profile made at the base of this cut and parallel to these structures shows strong sub horizontal reflectors that correspond to the level of lateritic concretion and the altered layers of the Cretaceous geological unit. In Figure 02 a layer of material supposedly used for grounding with approximately 2 meters thick can be seen along the first 80 meters from NE to SW. It is observed in the interval between 0 and 35 meters faults with characteristics of horsts and grabens with depths greater than 10 meters. From the range of 40 to 75 meters can be seen the movement and rotation of the layers caused by faults with possible listric character. From 80 meters to $180 \mathrm{~m}$, Negative Flower structures appear, caused by regimes of strike-slip / transtensional faults. It is possible to see fault zones noted on the surface mark displacement. In these zones of disturbance of the layers there is development of features in antiform and sinform that are associated to the kinematics of the faults, compatible with the surface presented deformation. Some faults that present high diving angle may be suggestive of transcurrent/transverse faults (negative flower structure), as indicated by Silva et al (2007). In Figure 03, the regions limited by green lines represent null signal, possibly caused by the equipment battery oscillations during the field work. In the interval between 0 and 60 meters, it is observed the layers movement, forming an antiform and sinform caused by a normal fault. It represents the other profile, located downstream of this site, also on the banks of the Rio Negro. However, has larger dimensions, where the features are best observed. At the top of this profile, the lateritic concretion was also displaced by the fault, which was mainly in the low block of the fault. In the adjacent section $(E-W)$ other faulted surfaces that are parallel and obey the NW-SE orientation are noted. Features such as rotation of the layers, anastomosis and roll-over structures, drag folds along the surface (antiform and sinform) are characteristics denoted in these faults. In this profile it is possible to observe the significant reject of the displacement of this fault, due to the kaolinite level (located above the reddish layer) next to this one. In addition, the absence of the clayey horizon in the reddish layer is diagnostic of the erosion after the tectonic event. The GPR profiles made in this area show inclined reflectors of the tilting of the altered layers of the formation, as well as antiform and sinform features at the side of the deformation zone. At deeper levels the interface between the kaolinized and oxidized levels could be observed, which resulted in a marked decrease in the signal.

\section{Discussion}

The cut of land located in the Turismo avenue, left bank of the Rio Negro, comprises soil levels of the Alter do Chão Formation, since the weathered layers are located in subsurface. At the base, the mottled kaolinitic horizon is observed, underlain by the laterite crust (a little thick) and a pisolithic centimetric level above it and, to the top, yellowish sandy-clay soil. The irregular distribution of the lateral horizon derives from the displacement due to normal faults N20W to N30W, as described by Silva (2005), Silva et al. (2007) and Val et al. (2014). The structural arrangement describes two families of normal faults that plunge either to SW or to NE, which promote the rotation of the blocks to the northeast. However, due to the occurrence of soil faults, the lack of continuity to the top due to rheological characteristics of the material and the height of the cutting height are limiting factors that limit the structural faults (planar or curviplanes, for example). According to the aforementioned authors, these faults show listric geometry, with rotation of blocks, developing grabens and horsts. Finally, when correlating with the subsurface structures obtained by the GPR survey, observed in Figures 2 and 3, with the studies performed by Silva (2005), Silva et al. (2007) and Val et al. (2014), it is concluded that the features observed in the outcrops present a representative continuity of the regional structural trend in depth. Thus, allowing a better basis for the understanding of the Cenozoic tectonic evolution of the Alter do Chão formation. 


\section{Acknowledgments}

I would like to thank the Federal Rural University of Rio de Janeiro (UFRRJ) for having given me scientific, ethical and philosophical support for the development of this research, Saulo thanks for INCT Criosfera for support, Clauzionor thanks DPM/UNESP for kindly giving in the data to work and Petrobras (UO-AM).

\section{References}

Almeida, F.F.M. de, 1969. Diferenciação tectônica da Plataforma Brasileira (Tectonic differentiation of the Brazilian Platform). Proceedings 33rd. Brazilian Geological Congress, Salvador(BA), Brazil, vol. 1: 29-46.

Arora et al. (06 co-authors), 1999. 2D geoelectrical model for the Parnaíba conductivity anomaly, north-northeast Brazil and its tectonic implications. Tectonophysics, 302: 57-69.

Bott, M.H.P., 1982. Stress based tectonic mechanisms at passive continental margins. In: Scrutton, R. A. (Ed.), Dynamics of Passive Margins. AGU Geodynamic Series, Washington (DC), USA, vol. 6: 147-153.

Chandler, V.W., Kiski, H.S., Hinze, W.J. \& Braile, L.W., 1981. Analysis of multisource gravity and magnetic anomaly data sets by moving-window applications of Poisson's theorem. Geophysics, 46: 30-39. Figueiredo, M.C.H., 1980. Geochemistry of high-grade metamorphic rocks, Northeastern Bahia, Brazil. Ph. D. Thesis, Department of Geology of the University of Western Ontario, Canada.
Silva, C.L. Análise da tectônica cenozóica da região de Manaus e adjacências. Tese (doutorado) - Universidade Estadual Paulista, Instituto de Geociências e Ciências Exatas, 2005. 282p.

Silva, C.L., Morales, N., Crósta, A.P., Costa, S.S., Jimenez-Rueda, J.R. 2007. Analysis of tectonic-controlled fluvial morphology and sedimentary processes of the western amazon basin: an approach using satellite images and digital elevation model. Anais da Academia Brasileira de Ciências, no prelo, v.4, 71, 2007.

Turner, F.J. \& Werhoogen, J. 1960. Igneous and metamorphic petrology. 2nd ed., McGraw Hill, New York, USA.

Val, P.F.A.; Silva, C.L.; Santos, J.M.; Morales, N.; Harbor, D. 2013. Distribuição de knickpoints em bacias de drenagem na região de Manaus (AM) e seu potencial para o estudo neotectônico e evolução da paisagem. In: Fábio Luiz Wankler, Elizete Celstino Holanda, Marcelo Lacerda Vasquez. (Org.). Contribuições à Geologia da Amazônia. Sociedade Brasileira de Geologia (NO), 2013, vol. 8, pp: 7-24.

Val, P.F.A., Silva, C.L., Harbor, D., Morales, N. Amaral, F.R., Maia, T..F.A. 2014. Erosion of an active fault scarp leads to drainage capture in the Amazon region, Brazil. Earth Surface Processes and Landforms, 13p

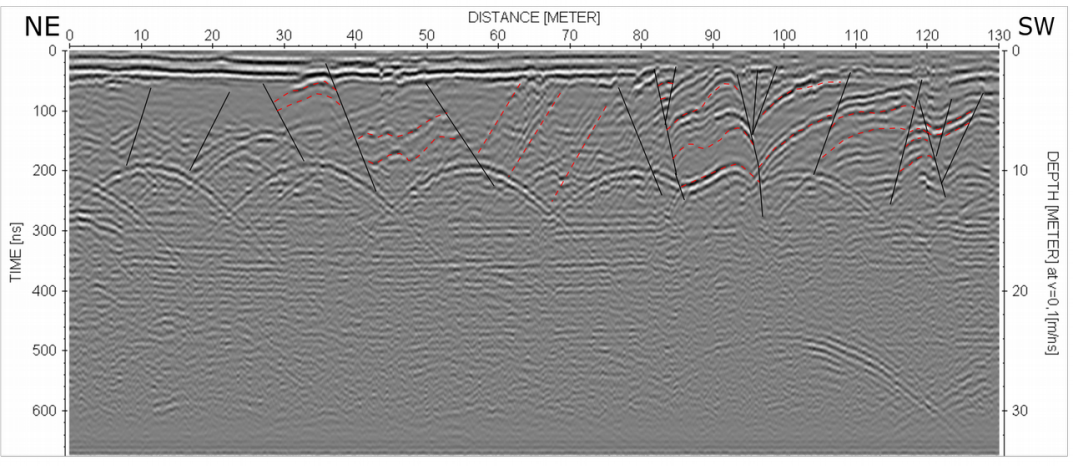

Figure 2 - GPR section 1

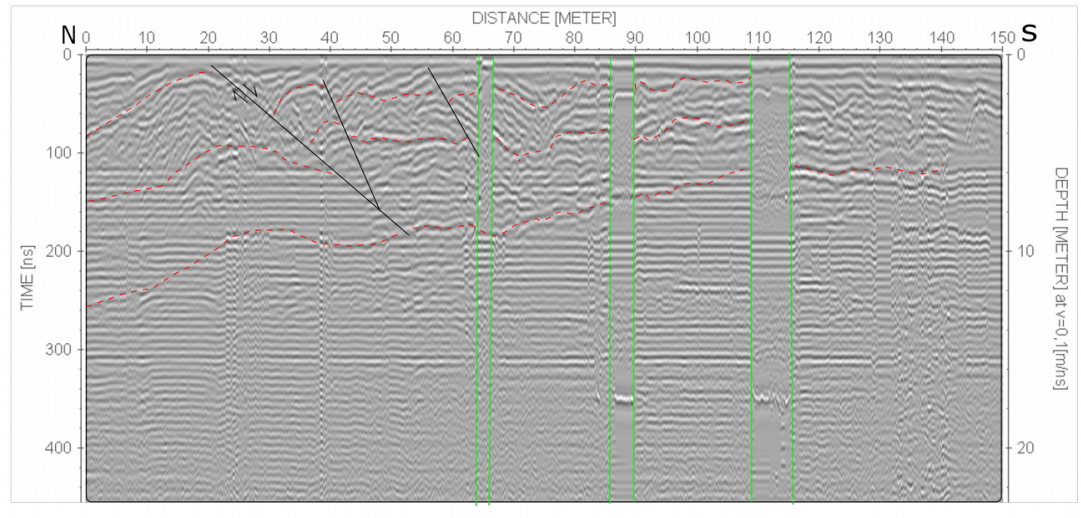

Figure 3 - GPR section 2 